\title{
Reflections on the Role of Ubuntu as an Antidote to Afro-Phobia
}

\author{
Gideon Muchiri Kaungu* \\ University of Pretoria, South Africa \\ Gideon.Muchiri@gmail.com
}

\begin{abstract}
This article argues that xenophobic acts towards black foreigners remain a human rights challenge in South Africa. Foreign nationals, mostly black Africans, continue to experience physical attacks, discrimination and looting of businesses, as well as targeted crime. Prevalent xenophobic attitudes continue to trouble the conscience of all well-meaning South Africans. There is ample evidence that xenophobia has morphed into afro-phobia, the hatred of black foreigners. Xenophobia continues to evolve and attackers are increasingly linking the presence of foreign nationals to socio-economic challenges facing the country. This article argues that, even though South Africa's Constitution does not expressly identify Ubuntu as a national value, it does recognize customary law and many of its provisions are anchored in Ubuntu philosophy. This article proposes Ubuntu, or African "humanness" whose "natural home" should be located in South Africa, as a pragmatic social intervention and a morally sustainable solution to address xenophobia that would be acceptable to both South Africans and foreign nationals.
\end{abstract}

\section{Keywords}

Afro-phobia, Ubuntu, social cohesion, xenophobia

\section{INTRODUCTION}

The article is divided into two main sections. The first defines xenophobia and introduces the phenomenon as an important contemporary human rights issue in South Africa today, briefly outlining its history and assessing its current status. The article then develops the argument that South Africa mostly experiences black on black xenophobia, ie afro-phobia. The article uses the terms xenophobia and afro-phobia inter-changeably. An analysis of efforts by various actors to tackle afro-phobia follows. The section concludes with a discussion of the available legal and extra-legal mechanisms, which, it is argued, have not been utilized effectively to combat the phenomenon. 
The second part of the article introduces Ubuntu, the humanist tradition with roots in the African continent and which is anchored in all facets of South African legal and constitutional jurisprudence. Ubuntu, if fully embraced, could be an effective social intervention to address the prevailing xenophobic attitude often exhibited by black South Africans towards black African foreigners. The article demonstrates that, whereas Ubuntu is supported both by African traditions and by South African legal, constitutional and institutional jurisprudence, South African nationals have disregarded its spirit. The article demonstrates that indigenous African values of Ubuntu could be relied on to foster social cohesion and minimize xenophobia in South Africa.

\section{XENOPHOBIA IN SOUTH AFRICA}

Xenophobia encompasses "attitudes, prejudices and behaviour that reject, exclude and often vilify persons, based on the perception that they are outsiders or foreigners to the community, society or national identity". ${ }^{1}$ In South Africa, there is a consensus that the phenomenon is usually manifest in passive fear, negative attitudes and hostile perceptions among the populace, coupled with accompanying outward acts of overt individual or mob violence, hostility or discrimination against foreigners, inevitably resulting in loss of property and human life. ${ }^{2}$ These manifestations constitute an affront to the rule of law in South Africa, a country that not only boasts a highly progressive human rights and legal regime but whose government has in fact demonstrated a high level of generosity towards welcoming and hosting hundreds of thousands of refugees displaced by war and conflict from various countries in Africa.

In post-apartheid South Africa, xenophobia has proven to be a constant, shameful affront to the nation's social fabric that, like "a nagging sore tooth", refuses to go away. ${ }^{3}$ It is incontestable that the phenomenon is a

1 This working definition was adopted in "International migration, racism, discrimination and xenophobia” (publication prepared by International Labour Office, International Organization for Migration and Office of the UN High Commissioner for Human Rights, in consultation with Office of the UN High Commissioner for Refugees (UNHCR), for distribution at the World Conference Against Racism, Racial Discrimination, Xenophobia and Related Intolerance, August 2001) at 2, available at: <http://www.refworld.org/docid/49353b4d2.html> (last accessed 2 January 2021).

2 Centre for Human Rights, University of Pretoria The Nature of South Africa's Legal Obligations to Combat Xenophobia (2009, Pretoria University Law Press) at 80. See also G Maina, N Mathonsi, C Macconnel and G Williams "It's not just xenophobia: Factors that lead to violent attacks on foreigners in South Africa" (2011, African Centre for the Constructive Resolution of Disputes) at 2; and B Harris "Xenophobia: A new pathology for a new South Africa?" in D Hook and G Eagle (eds) Psychopathology and Social Prejudice (2002, Juta \& Co Ltd) 170.

3 D Everatt South African Civil Society and Xenophobia: Summary of Findings and Recommendations (2009, Atlantic Philanthropies) at 1. 
deeply rooted, widespread, on-going and evolving socio-legal problem in South Africa: ${ }^{4}$ one that is difficult to eradicate. ${ }^{5}$ In 2008 , thousands of foreign nationals living in various parts of South Africa were targeted and attacked in xenophobic violence, resulting in dozens of deaths and losses amounting to millions of Rand in lost businesses and livelihoods. ${ }^{6}$ The existing literature overly focuses on causes and the political dimensions, without addressing important socially and morally acceptable responses to the phenomenon. ${ }^{7}$

The available statistics portray a poignant story about xenophobia in South Africa. The International Organization for Migration records that, between 2008 and 2013, an average of three serious xenophobic attacks were documented across South Africa every week, cumulatively resulting in an average of 150 deaths annually. ${ }^{8}$ Data from the Consortium for Refugees and Migrants in South Africa (CoRMSA) shows that, between 2008 and 2011, at least 4,000 foreign nationals throughout South Africa were displaced from their homes or businesses by xenophobic violence. ${ }^{9}$ These attacks have persisted, with the University of the Witwatersrand in Johannesburg recording approximately 150,000 incidents in the past decade, most leading to deaths, injuries and destruction of property or displacement. ${ }^{10}$

4 Citing protracted instances of xenophobic attacks in the country, the University of Pretoria describes xenophobia as an epidemic in South Africa and "a pervasive part of South African society" that requires urgent multifaceted interventions to manage: see generally, Centre for Human Rights The Nature of South Africa's Legal Obligations, above at note 2 .

5 To appreciate the magnitude of xenophobic sentiment in South Africa, see the conclusions of South Africa's leading migration and social experts in the Southern Africa Migration Project (SAMP) and the Forced Migration Studies Programme, University of the Witwatersrand (FMSP) in the following publications: J Crush, S Ramachandran and W Pendleton Soft Targets, Xenophobia, Public Violence and Changing Attitudes to Migrants in South Africa (2013, SAMP Migration Policy Series No 64) at 47; and JP Misago et al May 2008 Violence Against Foreign Nationals in South Africa: Understanding Causes and Evaluating Responses (2010, Consortium for Refugees and Migrants in South Africa and FMSP) at 9.

6 “'Xenophobia': Violence against foreign nationals and other 'outsiders' in contemporary South Africa” (FMSP, Migration Issue Brief 3, June 2010) at 9, available at: <http://www. migration.org.za/wp-content/uploads/2017/08/\%E2\%80\%98Xenophobia\%E2\%80\%99Violence-against-Foreign-Nationals-and-other-\%E2\%80\%980utsiders\%E2\%80\%99-in-Co ntemporary-South-Africa.-Issue-Brief-3.pdf> (last accessed 3 January 2021).

7 For this view, see generally M Mafukata "Xenophobia: The evil story of the beginning of fascism in post-apartheid South Africa" (2015) 3/3 The International Journal of Humanities and Social Studies 30; and LB Landau Exorcising the Demons Within: Xenophobia, Violence and Statecraft in South Africa (2011, Wits University Press).

8 See generally The Effects of Xenophobia on the Integration of Migrants in South Africa: An NGO Perspective (2012, report prepared by the International Organization for Migration).

9 Protecting Refugees, Asylum-Seekers and Immigrants in South Africa During 2010" (2011, report by CoRMSA) at 67.

10 University of Witwatersrand "Monitoring xenophobic violence in South Africa", available at: <http://www.xenowatch.ac.za/about-xenowatch/> (last accessed 26 January 2021). See also, "South Africa: How common are xenophobic attacks?" (2 October 2019) 
To appreciate further how pervasive xenophobic sentiments are in South Africa, reference can be made to empirical data released by the Southern Africa Migration Project (SAMP) in 2013. These data reveal that one in four South Africans is willing to take communal action physically to prevent foreigners from operating businesses in their communities or to stop foreigners' children from enrolling in the same schools as their own. ${ }^{11}$ Furthermore, South African respondents to the SAMP survey were found to be more opposed to immigration into their country than citizens of other nations reviewed. In fact, about 80 per cent of South African citizens voiced support for a total prohibition on the entry of migrants into their country or, alternatively, stricter limits on migration. ${ }^{12}$

Recent surveys show that hostility towards foreign nationals living in the country could be increasing. Empirical data collected in surveys by the Gauteng City-Region Observatory (GCRO), and released in August 2014, reveal extreme xenophobic attitudes in townships like Mamelodi in Tshwane, where between 50 and 75 per cent of residents surveyed wanted all foreigners living in the country to be deported to their countries of origin. ${ }^{13}$

Predictably, and as a result of the protracted and widespread nature of xenophobic sentiment and actual incidents of violent attacks in South Africa between 1994 and 2018, many scholars have sadly concluded that South Africa is a hotspot of xenophobia. ${ }^{14}$ They portray the phenomenon as a deeply entrenched, on-going and evolving socio-legal problem in the country: one that will continue to feature as an important human rights issue for the foreseeable future. ${ }^{15}$

\section{XENOPHOBIA OR AFRO-PHOBIA?}

South Africa hosts migrants of various races and from different countries all over the world. These include black Africans, Asians and whites from places

contd

BBC News, available at: <https://www.bbc.com/news/world-africa-47800718> (last accessed 2 January 2021).

11 Crush et al "Soft targets, xenophobia", above at note 5 at 6.

12 Id at 4.

13 GCRO "Quality of life survey III: 2013" (2014) at 16, available at: <https://www.gcro.ac. $\mathrm{za} /$ research/project/detail/quality-of-life-survey-iii-2013/> (last accessed 3 January 2021).

14 For this view, see LB Landau, K Ramjathan-Keogh and G Singh "Xenophobia in South Africa and problems related to it" (2005, Forced Migration working paper series 13, Wits University) at 2; B Dodson "Gender and the brain drain" (2002) 23 SAMP Migration Policy Series 1; C Adjai and G Lazaridis "Migration, xenophobia and new racism in postapartheid South Africa" (2013) 1 International Journal of Social Science Studies 192; and C Steenkamp "Xenophobia in South Africa: What does it say about trust?" (2009) 98 The Round Table Journal 403.

15 For this assertion, see Dodson, ibid; Adjai and Lazaridis, ibid; and Steenkamp, id at $439-47$. 
like America, Europe and Australia. Incidents of xenophobic violence have been recorded in all parts of South Africa and from as early as $1994 .^{16}$

New elements of xenophobia in South Africa are becoming clearer by the day. Bronwyn Harris, a South African pathologist, first presented the "biocultural hypotheses" of xenophobia in 2001. She conceptualized xenophobia in terms of racism by black South Africans against black Africans, and even South Africans with a darker skin complexion and other biological, cultural or physical biological features. ${ }^{17}$

It does not escape notice that the overwhelming majority of the victims of xenophobic attacks in South Africa are predominantly black Africans from neighbouring countries like Zimbabwe and Somalia, or even darker skinned South African citizens. ${ }^{18}$ Empirical studies have highlighted a paradox that the perpetrators of these attacks on black African foreigners are mostly black South Africans. ${ }^{19}$

A 2014 GCRO survey found that white migrants from Europe and North America are favourably perceived in South Africa and are therefore less likely to experience xenophobia than black migrants, regardless of the nature of the socio-economic well-being of the foreigner. ${ }^{20}$ Another surprising aspect of this study is that black South Africans appear more hostile to black foreigners. In this study, a modest 23 to 35 per cent of white respondents in Gauteng expressed the sentiment that all foreigners should be expelled from SA. ${ }^{21}$ That figure, when contrasted with the 50 to 75 per cent of black respondents from the same region who want all foreigners expelled from the country, ${ }^{22}$ seems to suggest that xenophobia is taking a racial twist and that the attacks are biased towards black African foreigners.

For these reasons, experts have made a shocking prognosis that the nature of the phenomenon in South Africa is actually black on black xenophobia, or afro-phobia: the "hatred or fear of black Africans". ${ }^{23}$ To Jonathan Crush, black

16 N Valji "Creating the nation: The rise of violent xenophobia in the new South Africa" (2003, unpublished master's thesis, York University) at 1-2.

17 B Harris “A foreign experience: Violence, crime and xenophobia during South Africa's transition” (2001) 5 Violence and Transition Series 9.

18 Adjai and Lazaridis "Migration, xenophobia and new racism", above at note 14; MLJ Koenane "Xenophobic attacks in South Africa: An ethical response - Have we lost the underlying spirit of Ubuntu?" (2013) 1 International Journal of Science Commerce and Humanities 107; and Steenkamp "Xenophobia in South Africa", above at note 14.

19 Ibid.

20 J Crush (ed) "The perfect storm: The realities of xenophobia in contemporary South Africa" (2008) 50 SAMP Migration Policy Series 4.

21 GCRO "Quality of life survey III", above at note 13 at 16.

22 Ibid.

23 See for example, B Harris "A foreign experience", above at note 17 at 11; Crush (ed) "The perfect storm", above at note 20 at 7; GCRO Report on Xenophobic Attitudes (2009) at 1-2; Steenkamp "Xenophobia in South Africa", above at note 14 at 442; Adjai and Lazaridis "Migration, xenophobia and new racism", above at note 14; and Koenane "Xenophobic attacks", above at note 18 . 
Africans, who are often referred to in a derogatory term as makwerekwere, are seen as alien, different, inferior and despicable others who should "go home". ${ }^{24}$

In that respect, many have questioned how black South Africans could attack black Africans, especially those from countries that were accommodating to South African exiles during the anti-apartheid struggle. ${ }^{25}$ Furthermore, why does engagement between black Africans result in increased black on black xenophobia as opposed to brotherhood and social harmony? It is also worthwhile considering if South Africa really needs laws to govern social relations among its black inhabitants.

There have been some logical explanations for the increasing afro-phobia in South Africa. Primary among these is the rationalization that the country's black population is more likely than the white population to interact or engage with black foreign nationals. They are more likely to meet in predominantly black townships, on the streets, in the cities, in the work place, in public places like restaurants and in the country's public administration, such as in government offices, schools and hospitals. ${ }^{26}$ As there are no refugee camps in South Africa, the majority of refugees and other African migrants live in townships with the majority of South Africa's black population. Most of South Africa's townships are overcrowded, resulting in increased incidence of unemployment, crime, poverty and disease. Malaika wa Azania, a young South African writer, blames afro-phobia on black people's frustrations with the socio-economic conditions in the townships. She posits:

"Black-on-black violence and Afro-phobic attacks emanate from this construct [of socio-economic deprivation], hence we have 'xenophobic' attacks in townships - but never in suburbs where white foreigners from Europe and America own luxury stores and restaurants ... Our generation has the responsibility to reject the narrative that seeks to suggest that the problem in South Africa is so-called foreign nationals. That's a convenient narrative that doesn't address the root of the crisis in our country." 27

Given the constitutional obligation of the state to provide security to all inhabitants of the country, it is important to assess what the South African state has done, if anything, to alleviate afro-phobia in the past decade.

\section{DENIAL OF XENOPHOBIA}

With xenophobic attacks occurring year after year since 2008, there is little evidence that South Africa is making any major progress in addressing

24 See generally, J Crush, A Chikanda and C Skinner (eds) Mean Streets, Migration Xenophobia and Informality in South Africa (2015, International Development Research Centre) at 1-24.

25 Crush (ed) "The perfect storm", above at note 20 at 7.

26 Landau et al "Xenophobia in South Africa", above at note 14 at 8.

27 M WaAzania "The day Soweto shamed me" (op-ed, 25 January 2015) The Sunday Independent. 
xenophobia or afro-phobia in the country. In multiple instances when xenophobic attacks occur, the notable reaction by influential politicians and even senior state officials is to deny that xenophobia is the motivation for the attacks on foreigners and to blame them on crime. The following examples demonstrate this contention.

In 2008, when xenophobic violence broke out in the country, former President Mbeki made a public statement denying xenophobia was the motivation and instead blaming it on criminality. He declared that the masses were neither antipathetic towards, nor did they hate, foreigners. ${ }^{28}$ More recent statements support the argument that denialism continues, and that xenophobia is downplayed as a major human rights issue in the country. For instance, in 2013 the South African Cabinet issued a statement to the effect that: "[c]ommunities must be vigilant against the possible resurgence of criminal violence targeting foreign nationals. Cabinet is cautious not to label this violence as xenophobia because ... these acts may be driven primarily by criminality". ${ }^{29}$ The then Minister of International Relations and Cooperation, Maite Nkoana-Mashabane also issued a statement proclaiming: "[t]he looting, displacement and killing of foreign nationals in South Africa should not be viewed as xenophobic attacks, but opportunistic criminal acts that have the potential to undermine the unity and cohesiveness of our communities" ${ }^{30}$

In January 2015, when a wave of xenophobic attacks and targeted looting of foreign-owned shops affected Soweto Township in Johannesburg, the South African Police Service (SAPS) issued a televised statement, denying that the attacks were motivated by xenophobia. ${ }^{31}$ The denial of xenophobia by the police flies in the face of the reality that only foreign-owned shops were singled out and attacked and looted by the mobs in the Soweto attacks. This denialism continued during the 2015 xenophobic violence when the then Minster of Home Affairs, Malusi Gigaba denied elements of xenophobia and attributed the attacks to criminal elements. ${ }^{32}$ The African Diaspora Forum captured this stance of the denial of xenophobia by government officials in

28 P Simao "Mbeki denies xenophobia behind S African attacks" (3 July 2008) Reuters Online, available at: <https://www.reuters.com/article/idUSL03188349> (last accessed 3 January 2021).

29 "Statement on the Cabinet meeting of 29 May 2013", available at: <http://www.gcis.gov. $\mathrm{za} /$ content/newsroom/media-releases/cabinet-statements/statement-cabinet-meeting29May2013> (last accessed 2 January 2021).

30 "Somali refugees plea for protection" (7 June 2013) News 24, available at: <https://www. news24.com/News24/Somali-refugees-plea-for-protection-20130607> (last accessed 3 January 2021).

31 "Soweto violence not xenophobic: SAPS" (22 January 2015) ENCA News, available at: <https://www.enca.com/south-africa/soweto-violence-not-xenophobic-saps> (last accessed 2 January 2021).

32 “Analysis: Are foreign nationals stealing jobs in South Africa?" (17 April 2015) Mail and Guardian, available at: <http://mg.co.za/article/2015-04-17-analysis-are-foreigners-steal ing-jobs-in-south-africa $>$ (last accessed 2 January 2021). 
a protest letter to the South African government, published in the press in January 2015. The letter said:

\begin{abstract}
"Despite the escalation of violence over the past 6 years causing numerous deaths, the government has denied that there is xenophobia ... always questioning the nature of this violence and attributing it to 'crime', instead of recognising it for what it is - xenophobic violence ... This attitude, from our perspective, has condoned the violence and allowed it to reach institutional heights making things even more difficult for foreign nationals living in South Africa, but also for South Africans wishing for social peace and integration." 33
\end{abstract}

In December 2016, Johannesburg Mayor Herman Mashaba made a highly publicized xenophobic statement, blaming "foreigners" living in Johannesburg for the high rates of crime the city was experiencing and calling on them to leave the country. ${ }^{34}$ As expected, Mayor Mashaba's anti-immigrant statement was followed by anti-foreign public demonstrations, the most notable one being organized by a group calling itself The Mamelodi Concerned Residents in Pretoria. The aftermath of the protest was a spike in xenophobic attacks in Mamelodi Township, in which several foreign-owned properties were destroyed.

There is a near-consensus among observers that some influential politicians in South Africa continue to deny that xenophobia is a problem in the country and attribute its manifestations to "criminal" conduct. It is therefore worth considering what has been done to counter this criminality using the law. Statements by top opinion shapers and decision makers in South Africa ultimately to categorize xenophobic attacks as "normal criminal activity" support the contention by Misago et al, that there is a "regrettable lack of political will by senior state officials to act on xenophobia". ${ }^{35}$

\title{
PROGRESSIVE LEGAL REGIME
}

South Africa has a very progressive legal regime for welcoming and protecting refugees and migrants, which can also be utilized to combat xenophobia domestically. The state and its law enforcement institutions have, over the past decade, made commendable and demonstrable efforts to combat hate crimes. The UN Refugee Agency opines that, "South Africa has wonderful

33 "Government ignoring xenophobia: ADF" (25 January 2015) ENCA News, available at: <https://www.enca.com/south-africa/government-ignoring-xenophobia-adf> (last accessed 2 January 2021).

34 "Mashaba's 100 days in office speech met with mixed reaction" (2 December 2016) EyeWitnessNews, available at: <https://ewn.co.za/2016/12/02/mashaba-s-100-days-in-of fice-speech-met-with-mixed-reaction $>$ (last accessed 3 January 2021). Misago et al May 2008 Violence, above at note 5 at 227. 
legislation. They also have some of the highest standards when it comes to domestic law, but it is the implementation of these laws that is the problem". ${ }^{36}$

South Africa's domestic laws place an obligation on the state to protect foreign nationals living in the country against attacks by non-state actors, such as mobs and private citizens. ${ }^{37}$ The Bill of Rights in the Constitution of the Republic of South Africa of 1996 (the Constitution) protects an array of civil, political, cultural and socio-economic rights for "everyone" residing in the republic, including nationals and foreigners. ${ }^{38}$ The most pertinent of these rights, in the context of xenophobia, are: the right to life; 39 equality before the law; ${ }^{40}$ the right to own property; ${ }^{41}$ and the right to access the courts for the administration of justice. ${ }^{42}$

Indeed, under South African law, unless otherwise expressly stated, foreign nationals are afforded the same protection and suffer the same restrictions as citizens. ${ }^{43}$ The Promotion of Equality and Prevention of Unfair Discrimination Act even contains a specific provision on xenophobia. It provides that "practices associated with xenophobia and assumptions of a discriminatory nature" should be interpreted as discrimination on the basis of "nationality", which "must be regarded as an aggravating circumstance for the purpose of the sentence" in criminal trials involving violations of the act. ${ }^{44}$

In a report, Human Rights Watch notes that, even with the existing progressive legal regime of which South Africa boasts, no-one has been convicted for xenophobic conduct, not even those who attack foreigners and destroy property. ${ }^{45}$ It is thus instructive that xenophobia does not occur in South Africa because of the absence of legal safeguards. Rather, it is attributable to the failure to implement available mechanisms, combined with complacency and inaction on the part of the state apparatus.

36 A Gupta, UNHCR senior regional protection officer, cited in K Harrisberg "A life of liminality in South Africa: Stories from Africa's refugees" (January 2015) Contributoria, available at: <http://www.contributoria.com/issue/2015-01/54550fc4083e5e7b1a00008a. html> (last accessed 3 January 2021).

37 Centre for Human Rights The Nature of South Africa's Legal Obligations, above at note 2. Examples of such laws include the Constitution of the Republic of South Africa (1996) and the Promotion of Equality and Prevention of Unfair Discrimination Act (2000) (PEPUDA).

38 The Constitution, chap 2.

39 Id, sec 11.

40 Id, sec 9.

41 Id, sec 25.

42 Id, sec 34.

43 Landau et al "Xenophobia in South Africa", above at note 14 at 13.

44 PEPUDA, sec 28(1).

45 D Mavhinga "Xenophobic violence erupts in South Africa" (24 February 2017, Human Rights Watch), available at: <https://www.hrw.org/news/2017/02/24/xenophobic-viol ence-erupts-south-africa> (last accessed 2 January 2021). 
A National Action Plan to Combat Racism, Racial Discrimination, Xenophobia and Related Intolerance (NAP) is now in place. The NAP describes xenophobia as "attitudinal orientation of hostility against non-nationals in a given population". ${ }^{6}$ When launching the NAP, President Cyril Ramaphosa (who has provided commendable leadership in the fight against afro-phobia and other hate crimes) acknowledged that "xenophobia cloaked in nationalism" manifests in society and that the state bears the primary responsibility to combat it. ${ }^{47}$ The NAP calls on all South Africans to exhibit values and behaviour that will help the nation to break with its hurtful past. The NAP takes a legalistic approach and proposes three key strategies (prosecution, protection and prevention) as the way forward to fight human rights abuses such as xenophobic attacks. Under the NAP, state and non-state actors are duty bearers, while everyone living within the jurisdiction of South Africa is a rights-holder. The NAP contains broad proposals to tackle xenophobia, including placing on the state ultimate responsibility for protecting the human rights of all South African residents. ${ }^{48}$ The NAP does not directly advocate Ubuntu as a value that should be promoted to address prejudice and xenophobia in the country.

An important question worth considering is whether the state should use the law or legal approaches to regulate xenophobia and other social forms of prejudice. Koenane argues that Ubuntu, the unwritten law of hospitality, is internalized among Africans and has a binding force. ${ }^{49}$ The author seeks to echo Koenane and propose that the state resort to pragmatic rather than legal measures and promote the use of social intervention mechanisms, such as the African humanist Ubuntu values, to curb xenophobia.

\section{UBUNTU AS A SOCIAL ANTIDOTE TO CURB AFRO-PHOBIA}

Black on black xenophobia, or afro-phobia, should be dealt with in a manner acceptable to the most affected: through the African cultural values manifest in Ubuntu. Ubuntu is the African humanist tradition that "addresses our interconnectedness, our shared and common humanity, and the responsibility to one another that flows from that connection". ${ }^{50}$ Ubuntu is a common foundation of many African cultures in South Africa and is a common cultural attribute of the majority of South Africa-bound black African migrants. Nussbaum defines Ubuntu in the following words: "the capacity in African

46 NAP at 9, para 3, available at: <https:/www.gov.za/sites/default/files/gcis_do cument/201903/national-action-plan.pdf> (last accessed 2 January 2021).

47 Id at 3.

48 NAP, above at note 46 at 37, para 124.

49 MLJ Koenane "Towards an ethical re-contextualisation of Freud's theory of personality" (2003) 15/1 Phronimon Journal of the South African Society for Greek Philosophy and the Humanities 1.

50 B Nussbaum "Ubuntu: Reflections of a South African on our common humanity" in MF Murove (ed) African Ethics: An Anthology of Comparative and Applied Ethics (2009, University of KwaZulu Natal Press) 100 at 101. 
culture to express compassion, reciprocity, dignity, harmony and humanity in the interests of building and maintaining community with justice and mutual caring". ${ }^{51}$ She further argues that Ubuntu can play a key role in solving a myriad of social cohesion issues facing South Africa, the continent and the world. ${ }^{52}$

The underlying value of Ubuntu is that the dignity of each and every person is honoured and respected regardless of distinctions of culture or race. Ubuntu propagates humaneness, sharing, caring and living in harmony with one's neighbours and the entire community generally. The ideal of Ubuntu and the way of life it inspires have, for many centuries, sustained African communities in South Africa and in Africa generally. In South Africa for instance, Ubuntu is understood as a "set of institutionalized ideals or values which guide and direct the patterns of life of Africans". ${ }^{53}$ Ideally, Ubuntu should foster social cohesion between individuals and cultures regardless of nationality, culture or other inert attributes used to distinguish people and make them targets of xenophobia.

Archbishop Desmond Tutu, one of democratic South Africa's founding fathers, coined the idea of a "rainbow nation" in which various races and ethnic groups live in peaceful coexistence and social cohesion. ${ }^{54}$ Tutu has been a key proponent for Ubuntu values in South Africa. He wrote in 1999: "[o]ne such [universal] law is that we are bound together in what the Bible calls 'the bundle of life'. Our humanity is caught up in that of all others. We are humans because we belong. We are made for community, for togetherness, for family, to exist in a delicate network of interdependence". ${ }^{55}$

Manifestations of xenophobia through violent attacks against foreign nationals not only constitute a violation of the victims' human rights but also jeopardize efforts towards social cohesion in the rainbow nation. On this point, Tutu further urged South Africans to embrace Ubuntu in a bid to bring about social cohesion and foster respect for human rights in the country. Foreigners are not excluded from Tutu's vision of the rainbow nation. In 1999, Tutu wrote:

51 B Nussbaum "African culture and Ubuntu: Reflections of a South African in America" (2003) 17/1 World Business Academy Journal 1 at 11.

52 Ibid. For their part, Keep and Midgley argue that Ubuntu is a distinctively African value that embodies deep notions of inclusivity. This makes Ubuntu an "ideal overarching vehicle for expressing shared values" and its application would lead to a genuine plural legal culture and social cohesion in South Africa: H Keep and R Midgley "The emerging role of Ubuntu-botho in developing a consensual South African legal culture" in F Bruinsma and D Nelken (eds) Recht der Werkelijkheid [law of reality] (2007, Reed Business) 29. Additionally, see generally $\mathrm{T}$ Metz "Ubuntu as a moral theory and human rights in South Africa” (2011) 11/2 African Human Rights Law Journal 532.

53 MN Mnyaka "Xenophobia as a response to foreigners in post-apartheid South Africa and post exilic Israel: A comparative critique in the light of the gospel and Ubuntu ethical principles" (2003, unpublished PhD thesis, University of South Africa) at 142.

54 See generally, DM Tutu No Future Without Forgiveness (1999, Doubleday).

55 Id at 196. 
"Ubuntu speaks of the very essence of being human ... My humanity is caught up, is inextricably bound up, in yours ... A person is a person through other persons ... We belong in a bundle of life ... A person is a person through other persons. I am human because I belong. I participate, I share... Harmony, friendliness, community are great goods. Social harmony is for us the summum bonum - the greatest good". ${ }^{56}$

Africans from across the continent understand and identify with Ubuntu values. To demonstrate this point, Kamwangamalu wrote in 1999:

"This concept [of Ubuntu] has phonological variants in a number of African languages: umundu in Kikuyu and umuntu in Kimeru, both languages spoken in Kenya; bumuntu in kiSukuma and kiHaya, both spoken in Tanzania; vumuntu in shiTsonga and shiTswa of Mozambique; bomoto in Bobangi, spoken in the Democratic Republic of Congo; gimuntu in kiKongo and giKwese, spoken in the Democratic Republic of Congo and Angola, respectively." ${ }^{7}$

Nussbaum buttresses this view by arguing, "[e]ven though Ubuntu is unscientific, all Africans understand the connections of past and present, human beings and nature, our common humanity, and a shared spirituality ... The new physics are, for South Africans, the golden threads of Ubuntu woven from the old traditional African fabric of interconnectedness". ${ }^{8}$ Having established that South Africans and other Africans in the country identify with the concept of Ubuntu, it is important to establish whether or not South African nationals have embraced the values espoused by Ubuntu and, if not, why.

\section{EXPLAINING THE CURRENT DISREGARD FOR UBUNTU BY MANY IN SOUTH AFRICA}

Ubuntu is a social philosophy that is uniquely African. Nussbaum argues that Ubuntu values address Africa's interconnectedness, common humanity and the responsibility that Africans owe to each other as a people. There is evidence that some South Africans are compassionate about the plight of the victims of xenophobic attacks. In the wake of the 2005 xenophobic attacks in Soweto Township in Gauteng, Enoch Mobeletse, a resident of Soweto, was quoted in 2015 stating, "[o]ur ancestors are ashamed of us. It is like we are spitting on their legacy of Ubuntu. As Africans, we failed them ... We failed to protect those vulnerable". 59

56 Id at 31.

57 N Kamwangamalu "Ubuntu in South Africa: A sociolinguistic perspective to a pan-African concept” (1999) 2 South-North Cultural and Media Studies 24.

58 Nussbaum "African culture and Ubuntu", above at note 51 at 25.

59 Enoch Molebeletse, a Soweto resident reacting to ongoing xenophobic violence in Soweto on 22 January 2015. See "Where is the Ubuntu in Soweto" (23 January 2015) The Sowetan. 
Conversely, there is evidence of disregard for Ubuntu values in South Africa. Kabwato is insightful when he argues that the omnipresent xenophobic attitude in South Africa and the recurrent xenophobic attacks only serve to expose a major disconnect between the Ubuntu African "rhetoric" and the reality in the country. ${ }^{60}$

Other studies have also highlighted a disturbing disregard for Ubuntu in South Africa. For example, it has been established that, while a majority of South African nationals from different races, including blacks, accept being "proudly South African", only a small minority of blacks want to identify themselves as "Africans". 61 This is because, as explained by some South African authors, for many black South Africans, "Africa spells failure and embarrassment". ${ }^{62}$ For them, Ubuntu extends only to apply among South African nationals, to the exclusion of foreign nationals living in the country, particularly those from elsewhere on the African continent. ${ }^{63}$

Other authors have controversially claimed that, to South Africans, Ubuntu is "considered an exclusive and peculiarly authentic trait of South Africans" and is a discourse of "national consciousness" to the exclusion of other Africans from outside the rainbow nation. ${ }^{64}$ Thus, these writers argue that, in South Africa, progressive and uniquely African social values like Ubuntu are construed narrowly, to benefit only South Africans to the exclusion of others. Fasselt, who writes on South Africans' exclusionist practices, presents the following argument:

"The overriding notion of African humanity, commonly known as Ubuntu, belies the [often] fraught relationship between South Africa and the continent, which has become particularly manifest in the violence committed against African immigrants residing in the country ... Ubuntu, as the political tool into which it has been transformed in post-apartheid nation-building rhetoric, excludes rather than includes African immigrants from the embrace of a shared humanity." ${ }^{65}$

60 C Kabwato "The peculiar pathology of xenophobic violence" (2008) 1 Rhodes Journalism Review, chap 1.

61 J Gibson "Overcoming apartheid: Can truth reconcile a divided nation?" (2006) 603/1 The Annals of the American Academy of Political and Social Science, cited in Adjai and Lazaridis "Migration, xenophobia and new racism", above at note 14 at 198.

62 A Krog Begging to Be Black (2009, Random House) at 236. MN Mnyaka, a South African theologist, argues that Ubuntu has failed because black South Africans, motivated by a sense of entitlement and exclusiveness, see themselves as somewhat superior and different from other Africans in terms of racial, material and cultural parameters: Mnyaka "Xenophobia as a response", above at note 53 at 103-04.

63 Adjai and Lazaridis "Migration, xenophobia and new racism", above at note 14 at 194.

64 For example, V Tadjo "Constructing the other: Learning from the Ivorian example" in TH Kupe and E Worby (eds) Go Home or Die Here: Violence, Xenophobia and the Reinvention of Difference in South Africa (2008, New York University Press) 225.

65 R Fasselt "Ke nako (It is time) to scrutinise Ubuntu: Reading South African hospitality towards African immigrants in Patricia Schonstein Pinnock's Skyline” in K Gallagher 
Nussbaum concludes that the disregard for Ubuntu has "darkened the spirit of modern-day Africa" and she affirms that the concept has a great potential to help shape a divided, fragmented world.66 Other authors contend that denying xenophobia or afro-phobia waters down the potential for African humanist values such as Ubuntu to be applied as potential solutions. ${ }^{67}$

\section{UBUNTU'S UNEXPLOITED POTENTIAL AS AN ANTIDOTE TO AFRO-PHOBIA}

The battle against afro-phobia will be won, not through legal instruments, but by winning the hearts of the people of the land. While Ubuntu should find a natural home in a multicultural and multiracial society like South Africa, this has not been the case. Xenophobic attitudes among sections of the South African public, manifest in violent actions, demonstrate the absence of hospitality or tolerance towards other Africans. ${ }^{68}$

Given Ubuntu, such targeted attacks on black Africans by black South Africans are unexpected. This is because Ubuntu places an obligation on South African nationals to be hospitable and welcoming towards their "African brothers and sisters through the fundamental issue of their shared and intertwined humanness". 69

The unexploited potential of Ubuntu as a social engineering tool to halt xenophobia in South Africa is captured in writings of various authors. Mnyaka, a South African theologist, argues that "an understanding and the implementation of the principles and values of Ubuntu can challenge and inspire South Africans to view and treat African immigrants differently". ${ }^{70}$

The African Centre for Migration and Society argues that, while xenophobia is a clear weakness in South Africa's social cohesion, embracing Ubuntu could play a role in fostering social cohesion in South Africa. It argues that Ubuntu "brings with it values of mutuality and shared humanity ... and is seen either as a means of achieving social cohesion or as the condition of social cohesion itself ... where there is Ubuntu there is social cohesion". ${ }^{71}$

Researchers conclude that pervasive xenophobic attitudes and consequent attacks undermine the spirit of Ubuntu and negate the aspirations of South

contd

Multiculturalism: Critical and Inter-Disciplinary Perspectives (2011, Inter-Disciplinary Press) 177 at 177.

66 Nussbaum "African culture and Ubuntu”, above at note 51 at 21.

67 L Amusan and S Mchunu "An assessment of xenophobic / afrophobic attacks in South Africa (2008-2015): Whither Batho Pele and Ubuntu principles?” (2017) 48/4 South African Review of Sociology 5.

68 Adjai and Lazaridis "Migration, xenophobia and new racism", above at note 14 at 202.

69 M Sanders Complicities: The Intellectual and Apartheid (2002, Duke University Press) at 125.

70 Mnyaka "Xenophobia as a response", above at note 53 at 141.

71 T Monson et al "Promoting social cohesion and countering violence against foreigners and other outsiders: A study of social cohesion interventions in fourteen South African townships" (2013, African Centre for Migration and Society) at 22. 
Africa's founding fathers, like Tutu, of building a multicultural and cohesive nation based on the rule of law and human rights for all. ${ }^{72}$ Ndebele notes that South Africans have an "intriguing capacity to be disarmingly kind and hospitable to others at the same time as being capable of the most horrifying brutality and cruelty". ${ }^{73}$

Koenane, a South African philosopher, supports the notion that Ubuntu values can be utilized to alleviate xenophobia in the country. ${ }^{74} \mathrm{He}$ rightfully diagnoses the problem afflicting South Africa as afro-phobia and black on black hatred, rather than xenophobia. ${ }^{75} \mathrm{He}$ attributes perpetual hostility towards black Africans in South Africa to disregard for the "Ubuntu spirit glue that holds African people together". ${ }^{76}$

Koenane further contends that there have been no major violent attacks against other racial or migrant groups in South Africa, including Europeans, American, South Americans or Australians, and that afro-phobia should be addressed using Ubuntu and other accepted African values. ${ }^{77} \mathrm{He}$ contends that, to address afro-phobia effectively, we should challenge violent acts morally and respond appropriately, through the Ubuntu world view. Koenane is of the opinion that, in embracing the spirit of Ubuntu, South Africans would be compassionate and empathetic towards black African migrants. This, he argues, would render black on black xenophobia obsolete because black Africans would not be seen as foreigners in South Africa but would be welcome guests. ${ }^{78}$

\section{UBUNTU VALUES ARE SUPPORTED BY SOUTH AFRICAN LEGAL AND CONSTITUTIONAL JURISPRUDENCE}

In an endorsement of its transformative nature, Bennet contends that the South African Constitution is anchored in the spirit of Ubuntu. ${ }^{79}$ This is because the constitution's preamble calls for the establishment of a society based on democratic values, social justice and fundamental human rights for all living in South Africa, regardless of their colour or origin. Likewise, the Promotion of National Unity and Reconciliation Act, the constitutive instrument of South Africa's Truth and Reconciliation Commission, ${ }^{80}$ explicitly indicates in its preamble that Ubuntu is one of its guiding values.

\footnotetext{
72 Adjai and Lazaridis "Migration, xenophobia and new racism", above at note 14 at 194.

73 N Ndebele The Cry of Winnie Mandela (2003, Aayebia Clarke) at 70.

74 Koenane "Xenophobic attacks", above at note 18.

75 Ibid.

76 Id at 110.

77 Ibid.

78 Ibid.

79 See generally, TW Bennet "Ubuntu: An African equity" (2011) 14/4 Potchefstroom Electronic Law Journal, part 1.

80 The Promotion of National Unity and Reconciliation Act 34 of 1995.
} 
Bennet, on his part, contends that Ubuntu even played a crucial role in the crafting of the final political consensus that brought an end to apartheid in South Africa. ${ }^{81}$ In supporting "talking issues through" and "listening", Nussbaum agrees with Bennet regarding the role of Ubuntu in ending apartheid and fostering reconciliation in the country by stating:

"I believe that some of the cultural dynamics behind South Africa's political miracle must be attributed to the patience, maturity, and reconciliatory skill that African leaders embody. Nelson Mandela and others found a way to talk issues through, until a dignified consensus was found. Credit is also due to the humility and commitment of white leaders who chose to listen. But, in the final analysis, the reconciliatory wisdom in the service of discovering and building our connection with each other is an inherent gift of African cultural heritage, a gift the world is just beginning to recognize and one that merits greater attention." 82

The decisions of South Africa's Constitutional Court and High Court present ample jurisprudence to demonstrate how the country's legal discourse has been influenced by Ubuntu over the years. Two landmark cases aptly demonstrate this contention. In Albutt $v$ Centre for the Study of Violence and Reconciliation ${ }^{83}$ the Constitutional Court stated that justice, fairness and civility are deeply rooted in traditional culture and therefore, inseparable from Ubuntu. ${ }^{84}$ This view was reiterated in $S v$ Makwanyane, where Justice Mokgoro commented on Ubuntu's role in upholding respect, human dignity and compassion: "[Ubuntu] envelops the key values of group solidarity, compassion, respect, human dignity, conformity to basic norms and collective unity, in its fundamental sense it denotes humanity and morality. Its spirit emphasizes respect for human dignity, marking a shift from confrontation to conciliation". 85

It is posited here that judicial application of Ubuntu should go hand in hand with restorative justice measures that, in the author's view, are appropriate to redress cases of xenophobic violence that result in the deprivation of foreign nationals' property. In Port Elizabeth Municipality $v$ Various Occupiers the Constitutional Court recognized the importance of legislation inspired by customary law to bring about restorative justice. ${ }^{86}$ In Mayelane $v$ Ngwenyama the same court alluded to the flexibility of customary law, in that it provides room for consensus-seeking, prevention of recurrent disputes

81 Bennet "Ubuntu", above at note 79 at 34 .

82 Nussbaum "African culture and Ubuntu”, above at note 51 at 23.

83 Masetlha $v$ President of the Republic of South Africa and Another 2008 (1) SA 566 (CC).

84 Albutt $v$ Centre for the Study of Violence and Reconciliation 20103 SA 293 (CC). At para 91, Froneman J argued that South Africa's participatory democracy was "in fact, an ancient principle of traditional African methods of government".

8620051 SA 217 (CC) 
and dispute resolution through measures such as restorative justice. ${ }^{87}$ Justice Mokgoro, one of South Africa's leading post-apartheid jurists, posits that Ubuntu principles have, over the years, crystallized into an African philosophy of life. ${ }^{88}$

\section{CONCLUSION}

Africa should embrace a sense of interconnectedness in order to overcome a myriad of moral and social challenges afflicting today's world. Indigenous methods of conflict resolution across Africa are anchored on the need to foster a spirit of peace and mutual respect for both individuals and groups, especially in times of conflict. A person who possesses Ubuntu attitudes is hospitable, friendly, generous, compassionate and caring for his fellow human beings. ${ }^{89}$

Xenophobia or afro-phobia, on the one hand, divides people along nationalities, ethnicities and races. Ubuntu, on the other hand, is an underlying social philosophy of African culture, which brings out Africa's ability to express compassion, harmony, tolerance, reciprocity, dignity and humanity in the interests of building and maintaining a cohesive community. ${ }^{90}$ Ubuntu is a glue that would bring black Africans together and end hostilities based on nationality.

Desmond Tutu successfully used Ubuntu principles to foster and promote peace building in South Africa during the Truth and Reconciliation Commission process that followed the end of apartheid. This article argues that black Africans, in post-apartheid South Africa, should pause and reconsider embracing the spirit of Ubuntu and use its values as a moral remedy or basis for a new discourse to counter pervasive xenophobia in the country. After all, the problem in the country is really afro-phobia and Ubuntu is uniquely African. Ubuntu could work in South Africa as a social remedy for past hostile attitudes towards black Africans in South Africa.

Professor Metz argues that Ubuntu presents a new conception of human dignity, to the extent that human beings have dignity by virtue of their capacity for community. Metz posits that Ubuntu, which is grounded in Southern Africa's world views, should be seen as a way of resolving contemporary social, moral and human rights dilemmas in South Africa and elsewhere. ${ }^{91}$ The author wholeheartedly supports Professor Metz's view.

8720134 SA 415 (CC), para 24.

88 Y Mokgoro J "Ubuntu and the law in South Africa" (paper presented at the First Colloquium on Constitutional Law, Potchefstroom, South Africa, 31 October 1997).

89 I Goduka African / Indigenous Philosophies: Legitimizing Spirituality Centred Wisdoms Within Academy (2000, Central Michigan University).

90 Nussbaum "African culture and Ubuntu", above at note 51 at 21.

91 T Metz "Ubuntu as a moral theory and human rights in South Africa" (2011) 11/2 African Human Rights Law Journal 532. 
It is possible for South Africa to overcome xenophobia or afro-phobia, even though its immediate past is filled with acts of hate and hostility towards fellow black Africans. Ali Mazrui observes that Africans have a short memory of hate. ${ }^{92}$ Nelson Mandela, the doyen of democracy in South Africa and regarded as a great statesman in Africa, argued that all South Africans should strive to live in a way that respects and enhances the freedom of others. ${ }^{93}$ Ubuntu fits within Nelson Mandela's vision, as it is the ultimate underlying social philosophy across African societies.

For centuries, Africans have used indigenous mechanisms to resolve conflicts and build peaceful coexistence. In terms of Ubuntu, every individual in African society will treat all others with dignity, compassion and respect, in the expectation that such treatment will be reciprocated. To achieve this, South Africans should start teaching their children, and indeed future generations, the values of Ubuntu, through which they will be able to communicate, find ways to cleanse and reconcile fully, and let go of hatred towards their African brothers and sisters.

Ubuntu values can be used to socially-engineer South Africa into a tolerant society that welcomes foreigners. To demonstrate that African values have worked elsewhere on the continent to heal deep social and ethnic hatred and divisions, Nussbaum gives the example of Rwanda. In 1994, the country was engulfed in ethnic hatred, hostility and genocide. Nussbaum highlights the fact that, with social engineering, the horrific 1994 ethnic genocide in Rwanda gave birth to reconciliation, peaceful coexistence and tolerance between Rwanda's major ethnic groups, the Hutus and Tutsis. She argues that this is proof that Africans can reconcile and forget the past. ${ }^{94}$ The wisdom of Ubuntu is therefore a perfect morally sustainable tool on which South Africans can rely to acknowledge their interconnectedness with the rest of Africa and to foster a prosperous and peaceful future for all living in the country.

\section{CONFLICTS OF INTEREST}

None

92 A Mazrui "Afro-Arab crossfire: Between the flames of terrorism and the force of Pax Americana" (paper presented at a special seminar sponsored by the Ethiopian International Institute for Peace and Development, Addis Ababa, Ethiopia, 5 December 2001), cited in Nussbaum "African culture and Ubuntu", above at note 51 at 23.

93 N Mandela A Long Walk to Freedom: The Autobiography of Nelson Mandela (1994, Little, Brown \& Company) at 544.

94 Nussbaum "African culture and Ubuntu", above at note 51 at 23. 